\title{
Preliminary study on willingness to pay for environmentally certified wood products among consumers in Malaysia
}

\begin{abstract}
Consumers are expected to demand and would be willing to pay a price premium for environment-friendly products stemming from the growing global environmental consumerism. While consumers in the developed countries are reported to be willing to pay a price premium for environmentally certified wood products, there is hardly any study on consumers' willingness in other markets. This preliminary study examines consumer willingness to pay a price premium for environmentally certified wood products in Malaysia. Data were obtained using a self-administered questionnaire distributed to 100 systematicallysampled, mall-intercepted respondents. Results indicated that some $38 \%$ of the respondents would be willing to pay an average of $14.4 \%$ more for environmentally certified wood products.
\end{abstract}

Keyword: Wood products, environment, certification, price premium, consumer 